\title{
National Curricula (Standards) in Public Administration (?)
}

Juraj Nemec, Andrei Larionov, Calin Hintea

\begin{abstract}
The goal of this paper is to assess the role of "national curricula" (national education standards) determining the contents of public-administration (PA) education. To achieve our goal we deliver five case studies describing relevant information about the situation in the Czech Republic, Poland, Romania, Russia and Slovakia, all with different approaches how to apply national PA curricula. In the final part we try to evaluate the pros and cons of "national curricula" from the point of view of the development of PA education. Our research documents that extremes (no regulation and too strict regulation) do not deliver in less developed countries; the right path for such conditions should be somewhere in between - indicative national curricula and also indicative course contents should be available - something that seems to be achieved in Romania somehow.
\end{abstract}

\section{Keywords:}

National curricula/standards, quality assurance, public-administration education

\section{Introduction}

High-quality education of future public servants is one of the major pre-conditions for modern governance, with utmost importance in the Central and Eastern Europe (CEE) region, still realising the transition from a centralised to a democratic, market-based system (some countries from this region are formally already "developed", but the reality is not so positive). Even as late as 2006 Dunn et al. thought that the lack of training of public employees affected the very ability of governments to implement their policies and programmes in the CEE region. The challenge is to develop and maintain adequate human administrative and managerial capacity and competence in the public sector, also via university education. 
Our paper deals with the following question: "How to assure the capacity of a higher-education system to prepare necessary professionals for the public sector?" There are several, but not too many, papers dealing with public-administration academic-education issues and very few (mainly our own) dealing directly with quality assurance and accreditation, with the focus on European conditions. The first summary of information about PA programmes in Europe in the post 1989 period was delivered especially via the EPAN network (also by books, e.g. Verheijen and Connaughton 1999, Verheijen and Nemec 2000). According to Hajnal (2015) throughout the 2000s, comparative research of PA education focused on a number of different dimensions, like the didactical approaches used (Newswander and Newswander 2012; Reichard 2002), the disciplinary composition, orientation and identity of the field (Bouckaert 2008; Cepiku 2011; Hanjal 2003, Hajnal 2004; Kickert and Stillman 1999; Kickert 2007; Nemec et al. 2012b and Reichard 1998). Hajnal identifies only two studies related to quality assurance and accreditation (Geva-May and Maslove 2007; Reichard 2010); in reality a few more exist, but may be difficult to find online (like selected chapters in Jenei and Karoly 2008 or our papers, like Nemec et al. 2011; Nemec et al. 2012a; Nemec et al. 2012b; Nemec and Spacek, 2013, Nemec et al. 2013; Nemec et al. 2015a and Nemec et al. 2015b).

The existing literature suggests that different tools exist to be used to manage the quality of educational programmes. The core mechanism is accreditation, with a variety of approaches to it in different countries. Educational programmes are subject to continuous evaluation by state authorities and the experts, including the international community. In public administration in Europe, the European Association for Public Administration Accreditation (EAPPA) is the leading organisation for evaluating educational programmes.

The goal of this paper is not assessing the systems of accreditation, but we want to focus on one specific feature of accreditation processes in the CEE region - the existence and role of "national curricula" (national education standards) determining the contents of public-administration education. To achieve our goal we deliver five case studies describing relevant information about the situation in the Czech Republic, Poland, Romania, Russia and Slovakia, all with different approaches. In the final part we try to evaluate the pros and cons of "national curricula" from the point of view of the development of public-administration (PA) education. The main research method is the secondary analysis of the national legislation and of the concrete selected programmes' documentation (curricula, syllabuses) available online.

\section{Czech Republic}

In the Czech Republic, the accreditation of academic programmes is delivered by the Accreditation Committee (AC) of the Ministry of Education, Youth and Sports 
- more an advisory than the final decision-making body. The AC does not publish any set of minimum standards that define the minimum general content requirements of public-administration study programmes. It also does not provide a list of areas where public-administration programmes can be provided (types of PA programmes).

This means that the Czech Republic does not have national PA curricula (some other branches may have them) determining the contents of different types of public-administration academic programmes. The rules only say that AC evaluates the contents of studies (if existing, with respect to the national curricula).

\section{Poland}

In Poland the State Accreditation Committee, connected to the Ministry of Higher Education and Science, is responsible for the accreditation of all academic programmes. In the past this Committee defined very rigid law-focused national curricula for all PA programmes (Table 1).

Table 1

Minimal Requirements for Administration Programmes in Poland (Bachelor's level)

\begin{tabular}{|c|c|}
\hline BASIC COURSES & SPECIFIC PROGRAMME COURSES \\
\hline $\begin{array}{l}\text { 1. Introduction to the law } \\
\text { 2. History of administration } \\
\text { 3. Public administration } \\
\text { 4. The constitutional system of public } \\
\text { organs } \\
\text { 5. Administrative law } \\
\text { 6. Administrative procedure } \\
\text { 7. Organisation and management in public } \\
\text { 8. Macro- and micro-economics } \\
\text { 9. Public economy law }\end{array}$ & $\begin{array}{l}\text { 1. Civil law and contracts in administration } \\
\text { 2. Labour law and public officials' law } \\
\text { 3. Public finances and finance law } \\
\text { 4. Sociology and methods of social } \\
\text { analysis } \\
\text { 5. Public procurement } \\
\text { 6. Criminal law } \\
\text { 7. EU institutions and law } \\
\text { 8. Statistics and demography } \\
\text { 9. Administrative legislation } \\
\text { 10. Execution procedure in administration } \\
\text { 11. Techniques of negotiation and } \\
\text { mediation in administration } \\
\text { 12. Local-government organisation }\end{array}$ \\
\hline
\end{tabular}

However, the fact that such rigid regulation is ineffective was recognised, and in 2011 the amendment of the Law regulating higher education introduced the new concept of the National Framework of Qualifications (henceforth NFQ) into the Polish system of higher education in accordance with the European Qualifications Framework formulated as an important tool of implementing Bologna process recommendations. The national curricula do not exist anymore. 


\section{Romania}

In Romania, the evaluation of higher-education programmes (including the ones in the field of public administration) is done by the Romanian Agency for Quality Assurance in Higher Education (ARACIS - Romanian acronym). According to the agency's website (www.aracis.ro), "ARACIS is an autonomous public institution, of national interest, having legal personality and its own income and expenditure budget. The agency is not subjected to political or any other types of interference." Several specialised/thematic commissions work within the framework provided by ARACIS, among which is Commission 5, which also includes the field of public administration.

After the regime change in 1989, the public-administration field underwent an evolution full of challenges (during communism public administration did not exist as a field of study at either the bachelor's or the master's level). Initially, a unique national curriculum was in place, with a massive focus on legal topics. Subsequently, this unique curriculum was abandoned, after significant pressure came from certain universities. For a long period after this, there was no type of national curriculum standards in place.

Recently, ARACIS has asked all of its commissions to conduct an assessment regarding the re-introduction of a single national curriculum. In the area of public administration, a decision was made regarding the existence of a more nuanced approach. This approach was endorsed also by the ARACIS Council and its leadership. Thus, among the standards for Commission 5, there are several key elements which are at the foundation of the development process for the public administration field, as follows:

A: Possible study programmes in the field of public administration are public administration, managerial assistance and secretariat, European administration, local police, public health and leadership of public sector.

B: There is a package of core/fundamental courses which should be common to all study programmes in administrative sciences (the exact name and the succession in the curriculum are to be determined freely by each university/department): administrative sciences, administrative law, constitutional law, public management, public policy, economics, sociology, logics, strategic planning, public finance and ethics in PA.

The curriculum needs to include at least 5 courses described as fundamental and the choice of these should be based on the mission of the programme and in accordance with the declared competences it intends to create.

C: The package of possible specialised courses includes: labour law and social security systems, urban planning/urbanism, comparative administrative systems, public relations, human resources management in PA, administrative law, public pro- 
curement, accounting in public institutions, project management, quality management in the public sector, communication in PA, decision-making in PA, internship.

At least 7 courses from the above package are mandatory. The exact name and the succession in the curriculum are to be determined freely by each university/department. An internship is mandatory, and it should represent at least $10 \%$ out of the total number of hours allocated for specialised courses.

D: There is also a package of complementary courses, which includes law and business administration, European law, public marketing, financial and fiscal law, management psychology, theory of state and law, civil law, political science, criminal law, urban development and planning and European public policies.

The introduction of these courses into the curriculum of the programme is not mandatory, and each university/programme can determine the opportunity of having such courses, depending on its own specifics.

The document which defines these standard curricula requirements for accreditation in public administration also includes extra information - specifically it indicates the core competences to provided, instructions how syllabi need to be drafted, instructions about the structure of the internship, guidelines for students' evaluation and limits for a maximum number of students who can be enrolled.

\section{Russia}

In Russia, the core players for accreditation are the Ministry and the Rosobrnadzor (Agency under the Ministry of Education and Science of Russia). The concrete accreditation and evaluation management structures differ according to the status of the school (federal universities function under different rule compared, for example, with regional universities).

The criteria for accreditation are determined by the educational standard. Several generations of standards have changed in Russia, also in the field of public administration, with different approaches concerning the criteria for the quality of educational programmes. Since the mid-1990s until today, three generations of standards have been replaced. The first standard, adopted in 1995, was designed to train students for a five-year training period. In the second generation of federal standards (2000), they were divided into bachelor's (four years of study) and "specialists" (five years of study). At the same time, bachelor's programmes in public administration were developed on the basis of the management standard. The main problem common to both standards was that the competence approach to education was not followed. It was not known which professional knowledge and skills should be formed (Barabashev and Kastrel 2012). The universities were limited in the choice of courses. They were determined mainly by the federal and regional modules of courses, prescribed in the standards. The module of courses determined 
by the universities themselves was not significant. But even in this situation, leading universities, as a rule, managed to form their own original programmes.

The signing of the Bologna Declaration by the Russian Federation changed the national educational policy, and its relative liberalisation took place. Selected leading universities were granted independence in the formation and approval of educational standards. In fact, there was a transition to a diversification of educational programmes. In the standards of the third generation, published separately for the $\mathrm{BA}$ and MA levels, also the index of formed competencies which corresponded to the Bologna Declaration appeared (Table 2 and Figure 1).

\section{Table 2}

2011 Russian national standard for PA (BA level)

\begin{tabular}{|c|c|c|}
\hline $\begin{array}{l}\text { Part of the } \\
\text { training module }\end{array}$ & Module of courses & $\begin{array}{l}\text { Credit } \\
\text { load }\end{array}$ \\
\hline \multicolumn{3}{|c|}{ Social and economic cycle ( 56 credit units) } \\
\hline Required part & $\begin{array}{l}\text { History, philosophy, foreign language, economic theory } \\
\text { (macro and microeconomics, world economy), political } \\
\text { science, sociology. }\end{array}$ & 25 \\
\hline Optional part & $\begin{array}{l}\text { Foundation of law, psychology, history of world civilisations, } \\
\text { foreign language in the professional field, theory of } \\
\text { organisation, state regulation of economy, foundation of } \\
\text { marketing, rhetoric, introduction to profession. }\end{array}$ & 31 \\
\hline \multicolumn{3}{|c|}{ Mathematical and natural-science cycle ( 33 credit units) } \\
\hline Required part & $\begin{array}{l}\text { Mathematics, information technologies in management, } \\
\text { concepts of modern natural sciences, statistics. }\end{array}$ & 16 \\
\hline Optional part & $\begin{array}{l}\text { Methods of taking managerial decisions, logics, ecology, } \\
\text { fundamentals of mathematical modeling of social and } \\
\text { economic processes, demographics. }\end{array}$ & 17 \\
\hline \multicolumn{3}{|c|}{ Professional cycle (131 credits) } \\
\hline Required part & $\begin{array}{l}\text { Theory of management, public administration, state and } \\
\text { municipal service, administrative law, civil law, constitutional } \\
\text { law, safety planning and forecasting, ethics of state and } \\
\text { municipal service, fundamentals of HR, social psychology, } \\
\text { history of public administration, business communications, } \\
\text { adoption and execution of government decisions, labor law, } \\
\text { foundation of record keeping. }\end{array}$ & 61 \\
\hline Optional part & $\begin{array}{l}\text { Public relations in government, land law, taxes and } \\
\text { taxation, regional management and spatial planning, } \\
\text { innovative management, sociology of management, project } \\
\text { management, marketing of territories, management } \\
\text { consulting, planning and designing of organisations, } \\
\text { municipal law. }\end{array}$ & 70 \\
\hline
\end{tabular}

The professional competencies were defined by the types of professional activity. This approach has enabled universities to choose one of the three educational 
programmes existing in Europe - Public Policy, Public Administration, Public Affairs, or to combine them (Figure 1).

\section{Figure 1}

Types of educational programmes and their activities

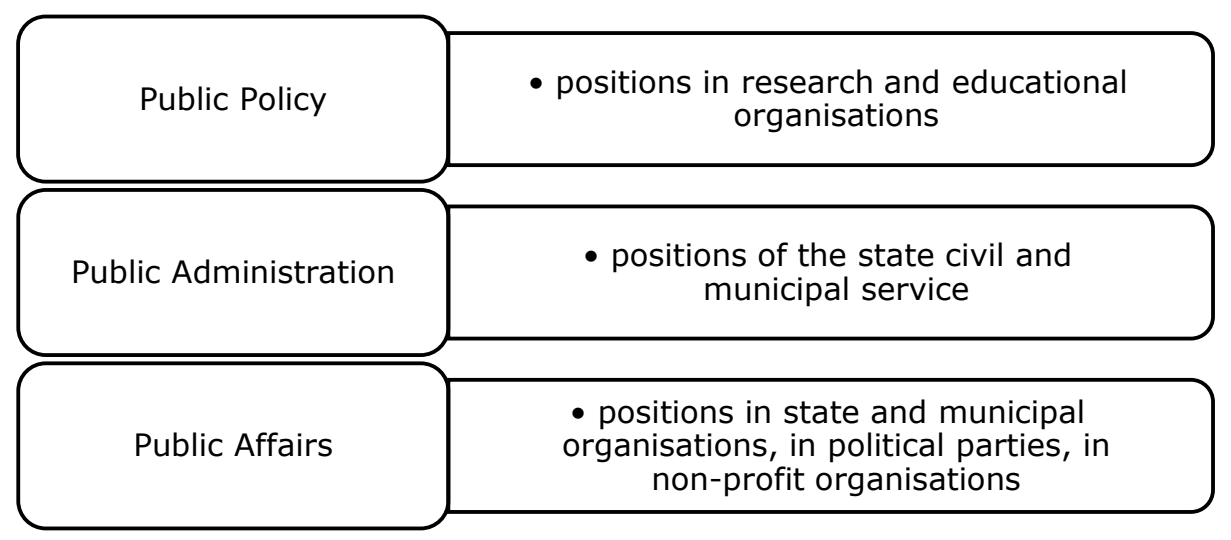

Adopted in 2014 year the so-called "three plus" standard provided universities with relative freedom in choosing courses and forming professional competencies. The relative independence and autonomy of universities inspire confidence that the system of higher education in Russia will continuously adapt to changing needs of the society and the need to develop knowledge. This is especially true for a modern public-administration system that is in a state of uncertainty (Barabashev 2016), needs employees who make effective management decisions (Rudenko 2010) and generally requires a management paradigm based on results (Gusarova and Ovchinnikova 2014).

In this development the rigid regulation of the contents of curricula is replaced step by step by defining relevant types of professional activities and their specific tasks and professional competencies, and determining whether they correspond to the Dublin description of the qualifications of a bachelor's. At the same time, the new standard classifies educational programmes into academic bachelor's (with research and teaching as the main types of professional activity) and practiceoriented (applied) bachelor's degrees. Only general requirements to the structure and content of the programmes are established, the universities have the right to independently determine their set of courses and their credit load by their own regulations. The PA educational programmes are expected to include the following training modules:

- Module 1 - Courses - which include the courses related to the required part of the programme and the courses related to its optional part; 
- Module 2 - Internships;

- Module 3 - State final examination - which concludes with granting a qualification.

The courses of the required part of the programme are mandatory for students, regardless of the profile of the programme. The set of courses of the required part necessarily includes courses on philosophy, history, foreign language, life safety and sports. A set of other courses in the required part, as well as courses in the optional part, are determined by universities independently. The courses of the optional part and internships should determine the profile of the programme.

\section{Slovakia}

Slovakia has the National Accreditation Committee, which is the advisory body of the Ministry of Education. The accreditation criteria are transparently defined, and two of them deal with the curricula, as follows:

\section{Criterion KSP-B1: The contents of the study programme}

"The contents of the study programme reflects in the sufficient level the contents of the national curricula for the given study area. Sufficient means that as minimum $3 / 5$ of the national curricula is included in the concrete programme curricula. For this purpose the national curricula (učebné plány) are created."

\section{Criterion KSP-B2: the level of the study programme}

The structure of the study programme, syllabuses and educational forms and methods shall be appropriate to achieve expected standards.

The core issue is the first requirement, which is totally concrete $-3 / 5$ of national-curricula courses (as a minimum) must appear in the curricula of the concrete study programme to be eligible for accreditation.

According to the current system, three possible national curricula for publicadministration academic education (all three levels - BA, MA and $\mathrm{PhD}$ ) are established in Slovakia, as follows:

1. Public Administration and Regional Development

2. Public Economics and Services

3. Public Policy and Administration

In the following text we present the contents of all three national curricula for the BA level. 


\section{Public administration and regional development}

$1^{\text {st }}$ year:

a) core: economic theory, corporate economics, finance

b) other: mathematics, statistics, marketing, law, foreign language, physical culture $2^{\text {nd }}$ year

a) core: economic policy, social policy, monetary policy, public finance

b) other: political sciences, accounting, management, foreign language, international trade, corporate finance, economic history, history of economic theories, mathematics II, physical culture

$3^{\text {rd }}$ year

a) core: microeconomics, macroeconomics, public-sector economics, public administration, regional economics and policy

b) other: constitutional law, political sciences II, taxation, banking, financial markets, socio-economic development, economic geography of Slovakia

Other possible courses for the BA level: economic geography, informatics, psychology, philosophy, economic analysis.

\section{Public economics and services}

Core courses: economic theory, microeconomics, macroeconomics, world economy, economic policy, social policy, finance, corporate finance, public economics I, theory of services, public sector, economics and management of services I, economics and management of public services I, economics and management of nonprofit organisations, corporate economics, special economy, regional and municipal economics, public administration, accounting, management, marketing, humanresources management $\mathrm{I}$, territorial management, territorial marketing, law, administrative law, civil law, business law, political sciences, demography, mathematics, statistics, informatics, foreign languages, management communication, social, moral and ethical aspects of a profession.

\section{Public policy and administration}

The core topics shall allow to know and to understand:

- theoretical and legal basics of public policy and public administration,

- public policy as a political process and social practice,

- sectoral policies in the public sector,

- policy actors, 
- constitution and other legal norms determining the functioning of the public administration,

- citizens,

- economic aspects of public policy and public administration,

- public finance,

- management in the public sector,

- information technologies in the public sector.

Other topics: social, moral and ethical aspects of a profession, public relations, communication, social policy, comparative public administration.

\section{Findings and conclusions}

This article compared five different systems of regulating the contents of publicadministration curricula in the CEE region. The most flexible system is in the Czech Republic, where the content of PA curricula is not regulated at all. The contents of the same course may also differ very significantly between programmes.

The Polish system was totally rigid at its start, now it is also almost totally flexible - the core task is to draft "qualifications"; accreditation is no longer connected with the contents. The impact of this change is too early to assess. Similarly to the Czech Republic, the contents of the same course may differ significantly between programmes.

The Russian system started from relatively comprehensive regulation of the contents of the curricula, but switched recently to very limited regulation. Similarly to Poland, the impacts of such change are difficult to assess - but in this "traditional" system, the existence of previous compulsory national curricula may determine the developments for a long period. When investigating PA curricula in Russia we found one specific problem - programmes draft very comprehensive syllabuses for any course (in some cases up to 20 pages) - with several pages devoted to expected qualifications. However, if you look at the course contents, in many cases it is the same as 20 years ago.

The Romanian case represents a mixed approach (created through consultation with the PA programmes from Romania) that helps to reconcile on the one hand the desire of ARACIS to have a unitary curriculum at the national level with the need of a mission-based construction of PA programme curricula, requested for example by EAPAA. In this context, PA schools from Romania have a reference standard at the national level but they can keep their own specificity in terms of how they view public-administration higher education. 
The highly regulated Slovak case especially shows that both "good" and "bad" practice could be found with respect to the way of defining the national curricula. Two out of three national curricula (Public Administration and Regional Development and Public Economics and Services) are almost copy-and-paste versions of existing programmes at leading faculties (experts of these faculties were responsible for drafting the national curricula). These two national curricula are not sufficiently interdisciplinary (compared to the European Association of Public Administration Accreditation standard - www.eapaa.org) - especially too many economic courses are included. The third national curriculum (Public policy and administration) is totally different and allows for a flexible but contextually "proper" construction of own curricula, related to the programme mission.

\section{What to conclude? Are national curricula "good" or "bad" practice in less developed countries?}

Our article provides examples of extremes (Slovakia with very rigidly regulated national curricula and the Czech Republic without any regulation, of switches (Poland and Russia) and also of a more "balanced" approach (Romania). Let us to try to assess extremes first.

The analysis of the contents of PA programmes in the Czech Republic indicates that "supply-based" programmes can be frequently offered - "supply-based" means that students receive what teachers are able to teach and not what they really want for their future profession. We provide two examples of such programmes from the Czech Republic and one from Poland.

1. Bachelor's programme in Public Management (CZE) - the programme is far from being a real public-management programme - the students have to follow the programme "City and Regional management" with one extra elective per semester (!). So the same programme is "sold" two times.

2. Management and Economics on the Public Sector programme (CZE) - this programme has 2 credits for public-sector-management-related courses, the rest are other courses, like general management.

3. Management and Organisation in PA (POL - 210 class hours) - however this programme does not include any specialised course. Its core courses are: personnel management, interpersonal communication, concepts and methods of management, strategic management, principles and methods of decision-making at the top level, structures of modern organisations, psychology of management, technics of negotiation and conflict resolution, group management, planning and organising of work, methods and techniques of management, results management and image building.

According to our opinion, the nonexistence of national standards may work in developed countries, where supply is regulated by demand and professional stan- 
dards (self-regulation) and also by functional labour markets (effective civil-service legislation and system). However, this approach may not work in less developed countries - as we show, the core risk is the "production of supply-based curricula". There exist several "transitional" factors limiting the chance for the creation of real mission-based PA curricula. On the supply side it is especially the lack of financial, material and human resources. Very specific factors can be found on the demand side, especially:

- "regional" demand - students prefer programmes as close to their home address as possible (so the distance is more important than contents)

- "diploma" and not skills demand - in politicised and patronage-based civil-service systems, a diploma and connections are enough to get good appointment

- "excessive" demand - too high a proportion of the population continues to the university level, lack of public capacity is an opportunity for the private sector to create low-level programmes (to make a profit, not to deliver) - in the past, for example in Poland, more than 100 private academic PA programmes existed, most of them of rather limited quality. The interconnected factor is the "forced" demand - many new civil-service laws required a diploma, and those in practice had to acquire them somehow.

The opposite extreme of Slovakia (or the former situation in Poland) documents that also rigid regulation may not work. As we documented, the purpose for this can be the limited capacity of a national regulator to create internationally based, flexible and multidisciplinary national curricula. Moreover, if too high a proportion of courses must be included on the basis of a national standard, the flexibility of programmes to link the mission and the curricula can be limited (see the opposition of the ARACIS Commission 5 against one uniform standard in Romania).

Our research documents that both extremes (no regulation and too strict regulation) do not deliver; the right path should be somewhere in between - indicative national curricula and also indicative course contents should be available - something that seems to be somehow achieved in Romania.

\section{Acknowledgments}

The preparation of this paper was supported by GACR under the contract GA16$13119 S$ - Performance management in public administration - theory vs. practices in the Czech Republic and other CEE countries. 


\section{References}

Barabashev, A. 2016. "Crisis of State Governance and its Influence on Basic Administrative Paradigms of State and Bureaucracy." Public Administration Issues 2016(3), 163-194.

Barabashev, A. and T. Kastrel. 2012. "Directions for Improving the Federal Standard of Bachelor Education for Public Administration.” Public Administration Issues 2012(1), 78-98.

Bouckaert, G. 2008. “Teaching Public Administration: Some Trends in Europe." Közgazdaság 2008(3), 9-15.

Cepiku, D. 2011. “Two Ships Passing in the Night? Practice and Academia in Public Management." Public Money and Management 31(2), 131-138.

Dunn, W. N., K. Staronova and S. Pushkarev. 2006. Implementation: The Missing Link in Public Administration Reform in Central and Eastern Europe. Bratislava: NISPAcee Press.

Geva-May, I. and A. Maslove. 2007. "In Between Trends: Development of Public Policy Analysis and Policy Analysis Instruction in Canada, the United States, and the European Union.” In L. Dobuzinskis, M. P. Howlett and D. Laycock (eds). Policy Analysis in Canada: The State of the Art. Toronto: University of Toronto Press, 186-216.

Gusarova, M. and M. Ovchinnikova. 2014. "Management of Results in the Public Administration in Russia: Approaches and Results of Reform over the Last 10 Years.” Public Administration Issues 2014(1), 98-126.

Hajnal, G. 2003. "Diversity and Convergence: A Quantitative Analysis of European Public Administration Education Programs." Journal of Public Affairs Education 9(4), 245-258.

Hajnal, G. 2004. "European Curricula in Public Administration." EPAN, $6^{\text {th }}$ Annual Conference. Budapest, Hungary, 11-12 June 2004.

Hajnal, G. 2015. "Public Administration Education in Europe: Continuity or Reorientation?" Teaching Public Administration 33(11), 21-30.

Jenei, G. and M. Karoly. 2008. Public Administration and Public Policy Degree Programs in Europe: The Road from Bologna. Bratislava: NISPAcee Press.

Kickert, W. J. M. (ed.). 2007. The Study of Public Management in Europe and the United States: A Comparative Analysis of National Distinctiveness. London: Routledge.

Kickert, W. J. M. and R. J. Stillman (eds). 1999. The Modern State and its Study: New Administrative Sciences in a Changing Europe and United States. Aldershot: Edward Elgar. 
Nemec, J., A. Barabashev and D. Spacek. 2015b. "National Curricula and PA Education." Paper presented at the annual EGPA conference, Toulouse, 26.-28. August, 2015.

Nemec, J., W. Mikulovski, S. Setnikar Cankar and D. Spacek. 2012b. "Public Administration Accreditation in Central Europe: Does it Support Quality Improvements?" Paper presented at the EGPA annual conference, Bergen, 5.-8. September 2012.

Nemec, J. and D. Spacek. 2013. "Public Administration Accreditation in the Czech Republic and in Slovakia." In L. Furova and D. Spalkova (eds). Proceedings of the $17^{\text {th }}$ International Conference: Current Trends in Public Sector Research. Brno: Masarykova univerzita, 170-178.

Nemec, J., D. Spacek and P. Fanta. 2013. "Public Administration Accreditation in the Czech Republic and Slovakia: Main Systemic Problems." In T. Chang (ed.). Advances in Education Research. Shenzhen: International Conference on Education Reform and Management Innovation, 46-49.

Nemec, J., D. Spacek and P. Suwaj. 2015a. "Standards of Excellence and Public Management Education in Central Europe." In A. Rosenbaum (ed.). In Quest of Excellence: Approaches to Enhancing the Quality of Public Administration Education and Training. Bratislava: NISPAcee, 237-258.

Nemec, J., D. Spacek, P. Suwaj and A. Modrzejewski. 2011. "Does Public Administration Higher Education in CEECs Reflect Demands Created by NPM Reforms?" Review of Economic Perspectives - Národohospodársky obzor 11(3), 124-140.

Nemec, J., D. Spacek, P. Suwaj and A. Modrzejewski. 2012a. "Public Management as a University Discipline in New European Union Member States: The Central European Case." Public Management Review 14(8), 1087-1108.

Newswander, L. K. and C. B. Newswander. 2012. "Encouraging Cognitive Flexibility and Interdisciplinarity in Public Administration Programs." Administration and Society 44(3), 285-309.

Reichard, Ch. 1998. "Education and Training for New Public Management." International Public Management Journal 1(2), 177-194.

Reichard, Ch. 2002. "Experiments with New Teaching Models and Methods." International Public Management Review 3(1), 41-54.

Reichard, Ch. 2010. "Challenges of Public Administration Accreditation in a Fragmented Institutional Setting: The Case of Europe." Uprava 8(1-2), 37-53.

Rudenko, L. 2010. "Administrative Decision as an Indicator of the Functionality of the State Civil Service." Public Administration Issues 2010(2), 196-202. 
Verheijen, T. and B. Connaughton (eds). 1999. Higher Education Programmes in Public Administration: Ready for the Challenge of Europeanisation? Limerick: Centre for European Studies, University of Limerick.

Verheijen, T. and J. Nemec (eds). 2000. Building Higher Education Programmes in Public Administration in CEE Countries. Bratislava: NISPAcee. 